\title{
HUBUNGAN KEBAHAGIAAN DENGAN STATUS SOSIAL PADA KELUARGA DI KELURAHAN TANJUNG BATU
}

\author{
${ }^{1}$ Shatory F. S Maniku \\ ${ }^{2}$ J. S. V. Sinolungan \\ ${ }^{2}$ H. Opod
}

\author{
${ }^{1}$ Kandidat Skripsi Fakultas Kedokteran Universitas Sam Ratulangi Manado \\ ${ }^{2}$ Bagian Psikologi Fakultas Kedokteran Universitas Sam Ratulangi Manado \\ Email: shatory.maniku@gmail.com
}

\begin{abstract}
Happiness is a situation or good feelings, peaceful, and satisfied from human being. Social status is a description of a condition of some people or a society that seen from social and economics. That description are about education, income and so on. Purpose on this research is to know the relationship about happiness with social status of a family in Kelurahan Tanjung Batu. low social status classes. Statistical Methods: of data collected using questionaire. Number of subject total is 93. Using correlation of Pearson - product moment. Result: Result of this research seen on happiness table distribution, 88 subject (95\%) with good happiness and 5 subject (5\%) have bad happiness. From the social status table distribution, 43 subject (46\%) have high social status, 41 subject (44\%) have medium social status and 9 subject ( $10 \%$ ) have test result $r=0,044$ and $p=0,676$. Conclusion: there is no relationship between happiness and social status of a family.
\end{abstract}

Keywords: Happiness, Social Status, Family.

Abstrak: Kebahagiaan adalah suatu keadaan atau perasaan senang, tentram, damai, dan puas dalam diri seseorang. Status sosial adalah suatu gambaran tentang keadaan seseorang atau suatu masyarakat yang ditinjau dari segi sosial dan ekonomi. Gambaran itu seperti tingkat pendidikan, tingkat pendapatan dan sebagainya. Tujuan penelitian adalah untuk mengetahui ada tidaknya hubungan antara kebahagiaan dengan status sosial pada keluarga di kelurahan Tanjung Batu. Metode: Metode pengumpulan data dengan menggunakan kuesioner. Penelitian dilakukan pada 93 responden. Menggunakan uji statistik yaitu uji korelasi Pearson - product moment. Hasil: berdasarkan distribusi tabel kebahagiaan adalah sebanyak 88 responden keluarga (95\%) memiliki kebahagiaan yang baik, 5 responden (5\%) tidak bahagia. Berdasarkan tabel distribusi status sosial, didapati jumlah keluarga yang memiliki status sosial atas adalah sebanyak 43 responden (46\%), 41 responden (44\%) status sosial sedang, serta 9 responden (10\%) status sosial bawah. Sedangkan berdasarkan uji statistik dengan menggunakan uji korelasi Pearson - product moment didapatkan $r=0,044$ dengan $p=0,676$. Simpulan: tidak terdapat hubungan antara kebahagiaan dengan status sosial pada keluarga.

Kata Kunci: Kebahagiaan, Status Sosial, Keluarga.

Kebahagiaan adalah dambaan bagi setiap manusia di dunia. Kebahagiaan pada umumnya dianggap sebagai suatu tujuan akhir dari kehidupan dan sesungguhnya semua orang ingin bahagia. ${ }^{1}$ Kebahagiaan di dalam hidup menjadi suatu hal yang menjadi harapan tiap individu di dunia ini, bahkan semua orang pasti mendambakan kehidupan yang bahagia. Kata kebahagiaan seringkali dikaitkan dengan kondisi manusia dalam merasakan dan menikmati dunianya sendiri. ${ }^{1}$ Kebahagiaan menurut Kamus Besar Bahasa Indonesia adalah suatu perasaan bahagia, ketentraman hidup, kesenangan, keberuntungan, kemujuran yang semuanya bersifat lahir dan batin. Sedangkan menurut tatanan bahasa inggris, padanan kata Kebahagiaan adalah happiness, dimana 
happiness berarti sebuah emosi atau afeksi yang dicirikan oleh perasaan kenyamanan dan kepuasan. ${ }^{1}$

Pada tahun 1990-an, seorang peneliti bernama Ronald Inglehart mempublikasikan hasil survey kebahagiaan yang melibatkan sekitar 170.000 orang dari 16 negara. Didapati hasil, sekitar $81 \%$ orang merasa bahagia tanpa dipengaruhi oleh tingkat ekonomi yang tinggi maupun status sosial yang tinggi. Status sosial menurut Ralph Linton adalah sekumpulan hak dan kewajiban yang dimiliki seseorang dalam masyarakatnya. Setiap individu dalam masyarakat memiliki status sosialnya masing- masing. Status merupakan perwujudan atau pencerminan dari hak dan kewajiban individu dalam tingkah lakunya. Status sosial sering pula disebut sebagai kedudukan atau posisi seseorang dalam kelompok masyarakatnya. ${ }^{2,3,8}$

Kedudukan sosial artinya tempat seseorang secara umum dalam masyarakatnya sehubungan dengan orang lain, dalam arti lingkungan pergaulannya, prestisenya, dan hak- hak serta kewajiban- kewajibannya. ${ }^{5}$

Masyarakat pada umumnya mengembangkan dua macam kedudukan (status) yaitu Ascribed Status, yaitu kedudukan seseorang dalam masyarakat tanpa memerhatikan perbedaan-perbedaan rohaniah dan kemampuan kedudukan ini diperoleh karena kelahiran, dan Achieved Status, yaitu kedudukan yang dicapai oleh seseorang dengan usaha-usaha yang disengaja. Kedudukan ini terbuka bagi siapa saja, tergantung dari kemampuan masing-masing dalam mengejar serta mencapai tujuan-tujuannya. ${ }^{5}$

Tingkat kebahagiaan seseorang dapat dilihat dari status sosial seseorang. Status Sosial Ekonomi merupakan salah satu tolak ukur dalam menilai status sosial .Dalam Status Sosial Ekonomi didapati beberapa faktor yang mempengaruhi suatu Status Sosial seseorang maupun keluarga. Untuk mengukur suatu Status Sosial Keluarga harus didasarkan pada aspek-aspek seperti pendapatan keluarga, tingkat pendidikan orang tua, pekerjaan orang tua dan Status Sosial pada masyarakat itu sendiri. ${ }^{6}$
Status Sosial menurut Gerungan (1983) adalah suatu gambaran tentang keadaan seseorang atau suatu masyarakat yang ditinjau dari segi sosial dan ekonomi. Gambaran itu seperti tingkat pendidikan, tingkat pendapatan dan sebagainya. ${ }^{7}$ Kelas sosial adalah penggolongan atau pengelompokan sosial (stratifikasi sosial) yang biasanya dipakai untuk menunjukkan lapisan sosial seseorang berdasarkan kriteria ekonomi (kekayaan, pendidikan, dan pekerjaan). ${ }^{8}$

\section{METODE PENELITIAN}

Penelitian ini dilakukan dengan metode analitik, metode ini digunakan untuk mengetahui hubungan antar variabel terikat dan variabel bebas, yaitu variabel Status Sosial dan Kebahagiaan pada keluarga yang dilaksanakan pada bulan Desember sampai dengan Januari 2014. Populasi dalam penelitian ini adalah keluarga-keluarga yang ada dalam kelurahan Tanjung Batu Kecamatan Wanea kota Manado. Jumlah sampel sebanyak 93 keluarga. Pengambilan sampel menggunakan metode Simple Random Sampling.

\section{HASIL PENELITIAN}

Tabel 1. Distribusi Responden berdasarkan secara umum memiliki keluarga yang bahagia.

\begin{tabular}{c|c|c}
\hline $\begin{array}{c}\text { Kebahagiaan } \\
\text { Keluarga }\end{array}$ & Frekuensi & $\begin{array}{c}\text { Persentasi } \\
\text { (\%) }\end{array}$ \\
\hline Bahagia & 88 & $95 \%$ \\
Tidak bahagia & 5 & $5 \%$ \\
\hline
\end{tabular}

Dari Tabel 1 dapat dilihat bahwa 95\% keluarga merasa bahagia dan sebanyak 5\% keluarga merasa tidak bahagia.

Tabel 2. Penggolongan Responden berdasarkan status sosial atas, menengah dan bawah.

\begin{tabular}{c|c|c}
\hline Status Sosial & Frekuensi & Persentasi (\%) \\
\hline Atas & 43 & $46 \%$ \\
Menengah & 41 & $44 \%$ \\
Bawah & 9 & $10 \%$ \\
\hline
\end{tabular}


Dari Tabel 2 dapat dilihat bahwa status sosial atas sebanyak $46 \%$, status sosial menengah sebanyak $44 \%$ dan status sosial bawah sebanyak $10 \%$.

Tabel 3. Hasil Uji Analisis Korelasi Pearson dengan menggunakan bantuan SPSS 18.

\begin{tabular}{clr}
\hline & & \multicolumn{2}{c}{ Status } \\
Correlations & Sosial \\
\hline \multirow{4}{*}{ Kebahagiaan } & Pearson Correlation & 0.044 \\
& Sig. (2-tailed) & 0.676 \\
& $\mathrm{~N}$ & 93 \\
\hline
\end{tabular}

\section{BAHASAN}

Berdasarkan hasil penelitian yang diuraikan pada Tabel 3, dimana didapatkan $\mathrm{r}$ $=0,044$ dengan $\mathrm{p}=0,676$ dan $\alpha=0,05$ secara statistik tidak bermakna. Melalui penelitian ini didapatkan bahwa keluarga keluarga di kelurahan Tanjung Batu kecamatan Wanea kota Manado yang menjadi sampel dalam penelitian merasa bahagia dengan kehidupan mereka. Hal tersebut dapat dilihat dalam tabel 22, sebanyak 95\% atau 88 kepala keluarga dari jumlah responden merasa bahagia dengan kehidupan keluarga mereka. Dalam Tabel 21 dapat dilihat bahwa dari 93 keluarga yang menjadi responden, terbagi kedalam 3 kelas sosial yaitu kelas atas, kelas menengah dan kelas bawah yang diambil sebagai sampel. Pembagian kelas Status Sosial tersebut digolongkan melalui data karakteristik yang diisi oleh keluarga sebagai responden yaitu: pekerjaan bapak dan ibu, pendidikan terakhir bapak dan ibu, serta pendapatan keluarga per bulan. Oleh karena itu dalam penelitian ini tidak terdapat korelasi antara status sosial dengan kebahagiaan keluarga. Hal ini dapat dilihat dari semua responden yang terbagi atas status sosial bawah, menengah, dan atas yang memiliki keluarga yang bahagia.

Hasil penelitian ini sama dengan hasil penelitian yang dilakukan oleh Ronald Inglehart dalam World Value Survey yaitu tentang tingkat ekonomi yang sangat tinggi maupun status sosial serta pendapatan besar dan jabatan yang tinggi bukan merupakan sumber terpenting dalam menghasilkan kebahagiaan. Mendukung hasil penelitian ini, dapat dilihat juga dari survey yang dilakukan oleh The New Economics Foundation (NEF) tahun 2009 yang menggunakan indeks kebahagiaan dengan indikator yang mencakup pendapatan, perumahan, pekerjaan, masyarakat, pendidikan, lingkungan, pemerintahan, kesehatan, kepuasan hidup, keamanan serta keseimbangan antara pekerjaan hidup. Berdasar indikator dalam indeks kebahagiaan diatas, tidak selalu negara yang perekonomiannya maju atau pendapatan per kapita masyarakatnya tinggi memberikan kebahagiaan bagi masyarakatnya. ${ }^{9}$

\section{SIMPULAN}

Berdasarkan penelitian yang telah dilakukan mengenai hubungan kebahagiaan dengan status sosial pada keluarga di kelurahan Tanjung Batu dapat disimpulkan bahwa tidak terdapat hubungan antara status sosial ekonomi dengan kebahaagian keluarga.

\section{DAFTAR PUSTAKA}

1. Anisty A, Kwartarini WY, Moordiningsih, Uichol K. Orientasi Kebahagiaan Remaja yang Tumbuh di Kota dan Desa. Center for Indigeneous and Cultural Psychology \& Faculty of Psychology, Universitas Gadjah Mada 2009: 146-177

2. Anonim. 2008. Arti Definisi/ Pengertian Status Sosial \& Kelas Sosial - Stratifikasi / Diferensiasi pada Masyarakat. http://organisasi.org/arti-definisi-pengertianstatus-sosial-kelas-sosial-stratifikasidiferensisasi-dalam-masyarakat. September 2013.

3. Anonim. 2012. Pengertian dan Definisi dari Status Sosial. http://www.bisosial. com/2012/10/pengertian-statussosial.html?m=1. 19 September 2013.

4. Henny W. Kebahagiaan Menurut Dewasa Muda Indonesia. Universitas Taruma Negara 2010:1-16.

5. Anonim. 2011. Pengertian Peran Status Sosial, Nilai dan Norma. http://catatankuliahpraja.blogspot.com/2011/ 
Jurnal e-Biomedik (eBM), Volume 2, Nomor 3, November 2014

09/pengertian-peran-status-nilai-norma-

dan.ht,l?m=1\#!. 19 September 2013.

6. Dhani Q. 2010. Hubungan Status Sosial Ekonomi Orang Tua dengan Prestasi Belajar Siswa. http://dhaniquinchy. wordpress. com/2010/06/01/hubungan-status-sosialekonomi-orang-tua-dengan-prestasi-belajarsiswa/. 20 September 2013.

7. Salmah. 2013. Pengaruh Status Sosial Ekonomi Keluarga Terhadap Motivasi Melanjutkan ke Perguruan Tinggi di MAS
Pontianak. Universitas Tanjungpura Pontianak.

8. Anonim. 2013. Pengertian dan Definisi Kelas Sosial. http://boetarboetarzz. blogspot. com/2013/01/kelas-sosial.html. 29 Januari 2014.

9. Didin A N. Subjective Well Being ditinjau dari faktor Demografi. Fakultas Psikologi Universitas Muhammadiyah Malang 2013: 581-603. 